\title{
DIFFERENCE IN FERTILITY OF TWO LINES OF MICE SELECTED FOR DIFFERENT BODY CONFORMATION
}

\author{
R. B. MURRAY-PRIOR, MANIKA WODZICKA-TOMASZEWSKA, \\ S. K. STEPHENSON* AND W. SENIOR \\ Departments of Physiology and *Agricultural Biology, University of New England, \\ Armidale, New South Wales 2351, Australia
}

(Received 17th March 1975)

Dawson et al. (1972) selected two lines of mice on limb-bone length in relation to body weight. One line (HL) was selected for long limb bones in relation to body weight and this resulted in relatively long legs together with an increase in body weight. Conversely, the other line (LL) was selected for short limbs in relation to body weight, resulting in relatively short legs and a decrease in body weight. Subsequently, Wodzicka-Tomaszewska et al. (1974) showed that HL mice had larger litters and fewer were infertile than LL mice. The present study was designed to investigate the reason for this difference in fertility.

Animals were available from generation 24 of these two lines. At this stage of selection the inbreeding coefficients were 0.43 for HL and 0.35 for LL. Fortyseven HL females and $23 \mathrm{LL}$ females were housed and fed under the conditions described by Wodzicka-Tomaszewska et al. (1974). The mice were mated at approximately 8 weeks of age. The females were handled daily for 10 days before mating in a manner similar to that required for detection of the copulatory plug. Two females were left with a male from the same line for up to 10 days. The mice were examined at 08.00 and 18.00 hours daily and were weighed and separated from the male immediately a copulation plug was detected.

Ten days after the detection of copulation plugs the females were killed by cervical dislocation and the ovaries and uteri removed for examination. The uteri were dissected to determine the total number of embryos. The ovaries were fixed in formol-saline, dehydrated in ethyl alcohol, cleared in benzenemethylene green (Senior, 1969) and examined in terpineol for a count of the number of CL.

The results are shown in Table 1.

Table 1. The mean body weight, numbers of CL and embryos in two lines of mice selected for different body conformation

$\left.\left.\left.\begin{array}{lcccc}\hline \text { Line } & \begin{array}{c}\text { No. of females } \\ \text { pregnant/no. mated }\end{array} & \begin{array}{c}\text { No. of } \\ C L\end{array} & \begin{array}{c}\text { No. of } \\ \text { embryos }\end{array} & \begin{array}{c}\text { Body wt at } \\ \text { copulation }(g)\end{array} \\ \hline \text { HL } & 33 / 47 & 13 \cdot 2 \\ \text { LL } & 17 / 23 & 8.8\end{array}\right\} * * * \begin{array}{r}11 \cdot 4 \\ 7 \cdot 7\end{array}\right\}^{* * *} \begin{array}{r}27.5 \\ 19 \cdot 1\end{array}\right\} * * *$

*** $P<0.001$ 
Significant regressions were found for the number of CL on weight at copulation and also for the number of embryos on weight at copulation: $P<0.05$ for the HL mice, $P<0.01$ for the LL mice and $P<0.001$ for the results from both lines combined.

The time of mating, determined by the time of formation of the copulation plug, was found to be different in the two lines. The proportion of matings after 5 days of pairing was $62 \%$ in HL mice but only $39 \%$ in LL mice. At the end of the 10-day pairing period, however, the number of copulations was slightly lower in the HL mice $(70 \cdot 3 \%)$ than in the LL mice $(74 \%)$.

A difference in litter size had been noted for several generations. At generation 24, the mean litter size for the HL mice was 8.5 and for LL mice 6.4. This difference has increased in subsequent generations. The ovulation figures and numbers of embryos determined 10 days after copulation can therefore be related to the litter sizes for generation 24. The relationship between litter size and body weight is well established in the literature (see MacArthur, 1949; Falconer, 1953), and it has also been found that this is usually the result of differences in ovulation rate rather than uterine capacity (see Fowler \& Edwards, 1960). It is of interest that, though the mice used in this study were selected on relative limb length, they showed body weight differences and the same relationship of body weight with ovulation rate and litter size holds.

In the study of Wodzicka-Tomaszewska et al. (1974), involving generation 17 mice from the same lines, there was also a higher proportion of LL females with a total failure of conception. However, these mice were caged with males for 5 days, whereas the mice of the present study were kept with males for 10 days. The conception rates in the LL mice after 5 days of pairing were similar in both studies, suggesting a difference in the rate of release of hormones affecting mating behaviour. Further work is needed to determine the possible involvement of the males.

A further possible factor affecting conception could be the temperament of the mice. It was noticed in the earlier study that the LL mice were more nervous during handling. In this study, therefore, the females of both lines were subjected to handling for a period before being caged with males in order to avoid possible effects of this nervousness on mating and subsequent embryo development. This handling appeared to reduce the nervousness of the LL mice, but insufficient data have yet been collected to determine its precise effect on fertility.

\section{REFERENCES}

Dawson, N.J., Stephenson, S.K. \& Fredine, D.K. (1972) Body composition of mice subjected to genetic selection for different body proportions. Comp. Biochem. Physiol. 42B, 679-691.

Falconer, D.S. (1953) Selection for large and small size in mice. 7. Genet. 51, 470-501.

Fowler, R.E. \& EdWARds, R.G. (1960) The fertility of mice selected for large or small body size. Genet. Res. 1, 393-407.

MacArthur, J.W. (1949) Selection for small and large body size in the house mouse. Genetics, Princeton 34, 194-209.

SENIOR, W. (1969) Staining of animal tissues with the dye base of methylene green in benzene to facilitate identification and selection of material. Stain Technol. 44, 269-271.

Wodzicka-Tomaszewska, M., Stephenson, S.K. \& Truscotr, T.G. (1974) Effects of genotype and nutrition before mating on the reproductive performance of mice. Aust. F. biol. Sci. 27, 39-45. 